\title{
The Blood is Red Gold in Time of Saving a Life - Blood Donation During Corona Pandemic in Indian Scenario
}

\begin{abstract}
Anshika Yadav*
DNB Resident, Department of Immunohematology and Transfusion Medicine, Santokba Durlabhji Memorial Hospital, Jaipur, Rajasthan, India

*Corresponding Author: Anshika Yadav, DNB Resident, Department of Immunohematology and Transfusion Medicine, Santokba Durlabhji Memorial Hospital, Jaipur, Rajasthan, India.
\end{abstract}

\section{Introduction}

The novel coronavirus disease (COVID-19), which began in Wuhan, China, in December 2019, and has been declared a pandemic by the World Health Organization (WHO) on 11 March 2020 [1]. It is Caused by virus belonging to Beta coronavirus genus of Coronaviridae family which is named as SARS-CoV 2 [2]. The common clinical manifestations of COVID-19 range from fever, dry cough, fatigue, sore throat, shortness of breath whereas headache, nausea and diarrhoea are uncommon manifestations. The infection may be asymptomatic to multi-organ dysfunction to death [3]. Indian state, Kerala reported the first confirmed case on 30 January 2020, whereas in Rajasthan the first case was detected on $2^{\text {nd }}$ March 2020. The total number of COVID-19 infection are 62 lacs and 3.72 lacs deaths have occurred globally (Till 31 May, 2020), It has affected 199 countries and 2 international conveyances [4]. In India, it has caused 190609 confirmed cases, and 5408 deaths (Till 31 May 2020). SARS-CoV-2 being a respiratory tract infection, bronchoalveolar lavage fluid has the maximum load of the virus (93\%) [5]. Detection of virus in blood transfusions is yet to be established. Study conducted on 41 cases of COVID19 in Wuhan showed only $15 \%$ i.e. 6 in 41 cases of patients blood samples positive for SARS COV19 [6] and only 1 of 5 infected symptomatic family members showed viral RNA [7]. The virus detection in symptomatic patients is on $2^{\text {nd }}$ to $3^{\text {rd }}$ day after onset of symptoms. It poses various threat to transfusion services as in a retrospective study by Chang., et al. Viral RNA was detected in plasma samples of 4 blood donors stored at $2-8^{\circ} \mathrm{C}$ for 28 days out of 4995 asymptomatic donors tested for COVID-19 [9]. There is a potential risk of transfusion transmissibility of COVID-19 from blood donations of asymptomatic or pre-symptomatic donors.
Containment steps by the government to prevent community spread of COVID-19 in India

COVID-19 was declared as a Public Health Emergency of International Concern (PHEIC) by WHO on 30 January 2020 [9]. Screening of International passengers on airports for COVID 19 was started by Government of India and flights from affected countries like China and Italy were banned. The country was under lockdown for nearly 2 months in three phases: 21 days, 19 days and then 14 days to prevent community spread of COVID-19 infection. During lockdown period, OPD of hospitals were shut down and elective surgeries were postponed and only emergency services were functional. In view of this pandemic and national lockdown, the apex body of blood transfusion services in India, the National Blood transfusion council (NBTC), released guidelines on 25 March 2020 regarding implications on blood transfusion services and recommendation for the exclusion of at-risk donors [10].

\section{Blood transfusion services in India}

Blood transfusion services are decentralised in India with around 3000 licensed blood centres all over the country. Blood Centres in India are controlled by various organisations under the Ministry of Health and Family Welfare, Government of India [11]. The Blood Centres are either Hospital based or standalone Blood Centres. The collection capacities from both voluntary and replacement donations at these blood centres ranges from 1000 units to 70,000 units in a year.

Uncertain patterns of demand for blood components, reductions in the number of donations, and to loss of crucial staff because of sickness was managed by Transfusion professionals. The key activity for transfusion institutions during the lockdown period, wheth- 
er hospital-based or stand alone blood transfusion services, was to monitor the supply and demand so that sufficient blood stocks are maintained in order to support ongoing critical needs.

In this review article, we will discuss the impact and response to the COVID-19 pandemic on our voluntary blood donation program and innovations we made in blood donations.

Challenges to voluntary blood donation due to COVID-19 pandemic

COVID-19 pandemic has affected blood transfusion services right from blood donor shortage to the increase wastage of blood components. During previous viral outbreaks, a significant reduction in blood donations was observed. A $60 \%$ decline of blood donors were reported in Singapore during the SARS epidemic in 2003 [12]. In 2009, during the Influenza pandemic in 2009, 10-30\% fewer blood donations occurred worldwide [12].Such a decline is also observed during COVID-19 pandemic due to widespread infection across countries. Moreover, the fear of infection during visits to high risk areas like Hospitals, Blood Centres or during Hospitalisation was very prevalent in the healthy population. Due to the essential national lockdown, donors faced a lot of difficulties to reach the blood centres because of no transportation services. The possibility of asymptomatic/pre-symptomatic infection in donors and a false history of exposure further increase a risk of infection. Blood centres were also reluctant to conduct voluntary blood donation camps in view of risk of community spread of the virus and prohibition of mass gatherings by the Government of India.

Challenges faced by us during corona pandemic

Santokba Institute of Transfusion Medicine placed in north western part of India is a multi component regional blood center catering to the entire state of Rajasthan which functions $24 / 7$ to provide transfusion services to all the hospitals in the vicinity of Jaipur. The blood bank has more than 400 voluntary blood drives in a year and collection of around 40,000 blood units per year, with nearly $100 \%$ collection from voluntary blood donors, the blood bank has an air condition mobile van equipped with donor couch to accommodate four donors simultaneously, reaches donors at their doorsteps. $1^{\text {st }}$ case of COVID-19 pandemic in the Indian state of Rajasthan was reported on $2^{\text {nd }}$ March 2020 in Jaipur. There was drastic fall in voluntary blood donation during cold 19 pandemic. The abidance to social distancing norms, limitations on travel and social gatherings resulted in cancellation of blood donation drives thereby severely affecting voluntary donation and Blood collections. The Blood bank had to resort to replacement donation.
The deliberations between health officials, camp organisers and Blood Bank gave birth to new strategy for Blood collection. Under the new strategy smaller Blood donation camps with all social distancing norms in place and strict PPE as well as hand and donor couch sanitisation measures were adopted.

There is no compelling evidence that this coronavirus or any other respiratory viruses are transmitted by blood transfusions [5]. Nevertheless, out of an abundance of caution, we are using a robust health screening process for blood donors and followed a step wise approach which consists of following measures:

- Temperature check: Each donor went through a temperature check with Infrared Thermometer before entering donation premises. Donors having forehead temperature $>37.8^{\circ} \mathrm{C}$ on the donation date were rejected.

- Sanitisation and face mask: Proper hand sanitisation measures before, during and after donation were followed for each and every donor followed by compulsion of wearing a face mask. Face Masks were provided to the donors in case of non availability.

- $\quad$ Social Distancing measures: Understanding both the great need for blood donations and the present-day sensitivity to person to person contact due to COVID-19, we enhanced safety measures by practising proper social distancing at both our centre and mobile drives, refreshment and waiting areas by only allowing a certain number of people to be inside, and once they have checked in with our staff, we are asking donors to wait outside the blood mobile van with social distancing until there is a donor bed available for them and by following physical distancing practices by putting space between donors and donor beds.

- Blood pressure evaluation: Pulse rate and blood pressure of every donor was evaluated with the help of digital sphygmomanometer.

- Haemoglobin level and blood group test.

- In India, before blood donation, candidates had to complete a written questionnaire and undergo a brief health screening and a series of questions designed to ensure that a donor is healthy enough to donate in compliance with the donation eligibility criteria set by Indian Health Ministry and DGHS.

- In perspective of Corona pandemic, some new criteria have been introduced in the donor form which includes: 
- $\quad$ Prospective donors could not have had flulike symptoms within the 30 days before donation;

- Had close contact with suspected or confirmed covid-19 cases in the 30 days before donation;

- Or travelled abroad or corona containment zones in the past 30 days.

- Once accepted to donate blood, provided they agree to sign the informed consent form for blood donation and all infectious markers to be tested along with consent for all the new criteria that have been added in the donor form, all donors were made sure to eat something and drink plenty of water before donating.

- Before and After donation, in addition to extra sanitising and decontamination of surfaces within both blood bank and mobile van units. disinfection of donor-touched areas and hand sanitisation was done.

- A telephonic follow up was done If a donor develops any symptoms of illness within 14 days following donation.

- To ensure the health of employees, volunteers and staff, we took a wide range of precautions which includes Temperature check, Hand sanitisation, Social distancing and proper PPEs.
During lockdown period from 24 march to 31 may 2020 in 3 phases of lockdown; With all safety measures we had total 1771 $(1721 \mathrm{M}, 40 \mathrm{~F})$ donations $(\mathrm{n}=1771)$ including both voluntary (blood centre and mobile van) and replacement donations since $24^{\text {th }}$ march to $31^{\text {st }}$ May 2020 out of which 1220 (1184M, 36F) were voluntary donations and 551 were replacement donations $(547 \mathrm{M}$, $4 \mathrm{~F}$ ). Total number of deferrals were 296 in this period. Voluntary blood donations were done in blood centre, blood mobile van and outdoor blood donation camps. In house blood donation (35) was less as compared to outside blood drives (1185) which included 972 donations in blood mobile van and 213 donations in outdoor blood donation camps (Table 1-3).

\section{Conclusion}

The blood transfusion services are responsible to provide an uninterrupted blood supply during an outbreak of a pandemic. It requires coordination from every level right from the top government officials to the common general public who are potential donors. The plan of action has to be started at an early stage before the community spread so that the supply can be maintained. Mass media plays an essential role to make it possible with a combined effort from clinicians' side. Blood transfusion services should have better strategical plan to respond to challenges generated during a

\begin{tabular}{|c|c|c|c|c|c|}
\hline \multirow{2}{*}{ Duration } & \multirow{2}{*}{$\begin{array}{l}\text { No. of } \\
\text { camps }\end{array}$} & \multirow{2}{*}{$\begin{array}{l}\text { Total } \\
\text { defer }\end{array}$} & \multirow{2}{*}{$\begin{array}{c}\text { Collection from } \\
\text { camps }\end{array}$} & \multicolumn{2}{|c|}{ In house collection } \\
\hline & & & & Voluntary donor & Replacement donor \\
\hline $24 / 3 / 20$ to $31 / 3 / 20$ & 00 & 00 & 00 & $05(4 \mathrm{M}, 1 \mathrm{~F})$ & $22(22 \mathrm{M}, 0 \mathrm{~F})$ \\
\hline $1 / 4 / 20$ to $30 / 4 / 20$ & 23 & 96 & 386 & $11(11 \mathrm{M}, 0 \mathrm{~F})$ & $147(144 \mathrm{M}, 3 \mathrm{~F})$ \\
\hline $1 / 5 / 20$ to $17 / 5 / 20$ & 22 & 165 & 650 & $13(13 \mathrm{M}, 0 \mathrm{~F})$ & $231(231 \mathrm{M}, 0 \mathrm{~F})$ \\
\hline $18 / 5 / 20$ to $31 / 5 / 20$ & 05 & 35 & 143 & $06(6 \mathrm{M}, 0 \mathrm{~F})$ & $151(151 \mathrm{M}, 0 \mathrm{~F})$ \\
\hline $1 / 6 / 20$ to $30 / 6 / 20$ & 18 & 60 & 623 & $45(44 \mathrm{M}, 1 \mathrm{~F})$ & $369(368 \mathrm{M}, 1 \mathrm{~F})$ \\
\hline $1 / 7 / 20$ to $31 / 7 / 20$ & 17 & 155 & 994 & $27(27 \mathrm{M}, 0 \mathrm{~F})$ & $436(433 \mathrm{M}, 3 \mathrm{~F})$ \\
\hline
\end{tabular}

Table 1: Blood donation camps during lockdown period.

\begin{tabular}{|c|c|c|c|c|}
\hline Year & Period & Total no of camps & Voluntary donations (camps) & Replacement donations \\
\hline 2019 & 24 March to 31 May & 330 & 6380 & 00 \\
\hline 2020 & 24 March to 31 May & 50 & 1179 & 551 \\
\hline
\end{tabular}

Table 2: Comparison with previous year donations. 


\begin{tabular}{|c|c|c|}
\hline & Covid 19 challenges & Response to challenges \\
\hline $\begin{array}{l}\text { Blood donor } \\
\text { recruitment }\end{array}$ & $\begin{array}{c}\text { Decrease blood donors } \\
\text { Difficulty to reach blood centre in } \\
\text { lockdown situation } \\
\text { Fear in donors of infection or expo- } \\
\text { sure in hospital or blood centre. } \\
\text { Lack of blood donation camps } \\
\text { Asymptomatic donors } \\
\text { False history by blood donors }\end{array}$ & $\begin{array}{l}\text { Recruitment and identification of Repeat Regular voluntary donors } \\
\qquad \text { Social Media } \\
\text { Exemption for travel } \\
\text { Preparedness for end of pandemic Deferral criteria }\end{array}$ \\
\hline $\begin{array}{c}\text { Donor } \\
\text { eligibility }\end{array}$ & $\begin{array}{l}\text { Donors from contaminated zones. } \\
\text { Travel history from outside india or } \\
\text { red/ contaminated zones in india. } \\
\text { Asymptomatic donors }\end{array}$ & $\begin{array}{l}\text { Recruitment and identification of healthy voluntary repeat blood donors } \\
\text { Special screening or deferral criteria as per pandemic } \\
\text { Inclusion of travel history deferral criteria. } \\
\text { Exemptions for blood donors during lockdown } \\
\text { Use of social media for recruitment } \\
\text { Preregistration for blood donation exclusion of donor with following: } \\
\text { Flulike symptoms within the } 30 \text { days. } \\
\text { had close contact with suspected r confirmed covid-19 cases in the } 30 \text { days. } \\
\text { (c) or traveled abroad or corona containment zones in the past } 30 \text { days. }\end{array}$ \\
\hline $\begin{array}{l}\text { Blood donation } \\
\text { camps plan- } \\
\text { ning }\end{array}$ & $\begin{array}{l}\text { Limits on travel and large gatherings } \\
\text { by government. } \\
\text { Previously scheduled blood donation } \\
\text { postponed or cancelled. }\end{array}$ & $\begin{array}{l}\text { Adjustment of the number and size of blood donation camps. } \\
\text { Review of physical distancing requirements when choosing locations for } \\
\text { mobile blood van and outdoor camps. } \\
\text { Work with regular camp organisers and government communicators to } \\
\text { emphasise the importance of blood donation } \\
\text { Work with health authorities to coordinate public appeals for donation }\end{array}$ \\
\hline Staff safety & $\begin{array}{l}\text { Safety of staff from infection } \\
\text { Staff Shortage } \\
\text { Designated staff Shortage of PPE } \\
\text { Misuse of PPE }\end{array}$ & $\begin{array}{l}\text { Decrease exposure and Risk } \\
\text { Area sterilisation } \\
\text { Restricted entry } \\
\text { Staff rotation } \\
\text { Adequate Provision of PPE }\end{array}$ \\
\hline Donor safety & $\begin{array}{c}\text { Safety of donor from infection } \\
\text { Wellness of donors }\end{array}$ & $\begin{array}{c}\text { Pre screening of covid } 19 \text { signs and symptoms } \\
\text { Thermal screening } \\
\text { Hand sanitisation } \\
\text { Social distancing measures during donation and refreshment areas } \\
\text { Donor couch/sheet sanitisation } \\
\text { Use of santisable donor sheets in outdoor blood donation camps } \\
\text { Telephonic follow up }\end{array}$ \\
\hline Follow up & Donor follow up & Telephonic follow up \\
\hline
\end{tabular}

Table 3: Donor and donation challenges faced and response to maintain supply of blood during the COVID-19 pandemic. 
pandemic which focuses on shortage, wastage and supply of blood and components in cost-effective manners. There is no known end date in this Fight against coronavirus and the hospitals needs the help of blood and platelet donors and blood drive hosts to maintain a sufficient blood supply for weeks to come.

\section{Conflicts of Interest}

The author has no conflicts of interest to declare.

\section{Funding}

No funding sources.

\section{Ethical Approval}

The study was approved by the Institutional Ethics Committee.

\section{Bibliography}

1. "WHO director generals opening remarks at the media briefing on Covid" (2021).

2. Rabi FA., et al. "SARS-CoV-2 and Coronavirus Disease 2019: What We Know So Far". Pathogens 9.3 (2020): 231.

3. Wang D., et al. "Clinical characteristics of 138 hospitalized patients with 2019 novel coronavirus-infected pneumonia in Wuhan, China". JAMA 323.11 (2020): 1061-1069.

4. “Coronavirus disease 2019 (COVID-19) Situation Report - 72".

5. Wang W., et al. "Detection of SARS-CoV-2 in different types of clinical specimens”. JAMA 323.18 (2020): 1843-1844.

6. Huang C., et al. "Clinical features of patients infected with 2019 novel coronavirus in Wuhan, China”. Lancet 395.10223 (2020): 497-506.

7. Chan JF., et al. "A familial cluster of pneumonia associated with the 2019 novel coronavirus indicating person-to-person transmission: a study of a family cluster". Lancet 395.10223 (2020): 514-523.

8. Chang., et al. "Severe acute respiratory syndrome coronavirus 2 RNA detected in blood donations". Emergency Infection Disease 26.7 (2020).

9. Statement on the second meeting of the International Health Regulations. "Emergency Committee regarding the outbreak of novel coronavirus (2019-nCoV)" (2005).
10. National Guidance to Blood Transfusion Services in India in light of Covid-19 Pandemic (2020).

11. National Blood Transfusion Council.

12. Teo D. "Blood supply management during an influenza pandemic". ISBT Science Series 4 (2009): 6.

\section{Assets from publication with us}

- Prompt Acknowledgement after receiving the article

- Thorough Double blinded peer review

- Rapid Publication

- Issue of Publication Certificate

- High visibility of your Published work

Website: https://www.actascientific.com/

Submit Article: https://www.actascientific.com/submission.php Email us: editor@actascientific.com

Contact us: +919182824667 